University of Nebraska - Lincoln

DigitalCommons@University of Nebraska - Lincoln

Agronomy \& Horticulture -- Faculty Publications

Agronomy and Horticulture Department

8-2009

\title{
Effects of Nitrogen Supply on the Root Morphology of Corn and Velvetleaf
}

Kimberly D. Bonifas

University of Nebraska-Lincoln

John L. Lindquist

University of Nebraska-Lincoln, jlindquist1@unl.edu

Follow this and additional works at: https://digitalcommons.unl.edu/agronomyfacpub

Part of the Plant Sciences Commons

Bonifas, Kimberly D. and Lindquist, John L., "Effects of Nitrogen Supply on the Root Morphology of Corn and Velvetleaf" (2009). Agronomy \& Horticulture -- Faculty Publications. 422.

https://digitalcommons.unl.edu/agronomyfacpub/422

This Article is brought to you for free and open access by the Agronomy and Horticulture Department at DigitalCommons@University of Nebraska - Lincoln. It has been accepted for inclusion in Agronomy \& Horticulture -Faculty Publications by an authorized administrator of DigitalCommons@University of Nebraska - Lincoln. 


\title{
Effects of Nitrogen Supply on the Root Morphology of Corn and Velvetleaf
}

\author{
Kimberly D. Bonifas and John L. Lindquist \\ Department of Agronomy and Horticulture, \\ University of Nebraska-Lincoln, Lincoln, Nebraska, USA
}

Corresponding author - John L. Lindquist, Department of Agronomy and Horticulture, University of Nebraska-Lincoln, Lincoln, NE 68583-0817; e-mail jlindquist1@unl.edu

\begin{abstract}
Root morphology will affect interplant competition for soil nutrients. Research was conducted to assess fine root fraction, mean root radius, specific root length, root length density, and nitrogen $(\mathrm{N})$ uptake per unit fine root biomass of corn and velvetleaf over time and in response to nitrogen supply. Pots containing either corn or velvetleaf were embedded in the ground and received one of three $\mathrm{N}$ treatments. Plants were destructively sampled on 10 dates during each of two years and root subsamples analyzed using root scanning software. While corn root morphology was more responsive to $\mathrm{N}$ supply than velvetleaf, velvetleaf $\mathrm{N}$ uptake per unit fine root length was greater than that of corn at similar biomass. Results suggest that, in lieu of modifying root morphology to increase uptake efficiency when $\mathrm{N}$ is deficient, velvetleaf may invest more root biomass to produce a deeper tap root to reach nutrients deeper in the profile.
\end{abstract}

Keywords: maize, Zea mays L, velvetleaf, Abutilon theophrasti Medic, specific root length, root length density, biomass partitioning, ontogenetic drift, phenology, optimal partitioning theory, functional equilibrium, competition

\section{Introduction}

The ability of a plant to compete for soil nitrogen $(\mathrm{N})$ is dependent upon root morphological characteristics such as root radius, root length, and root surface area. While plants respond to limiting soil $\mathrm{N}$ by increasing the amount of biomass allocated to roots (Bonifas et al., 2005; Mooney et al., 1985; Hilbert, 1990; Robinson, 1986; Reynolds and D'Antonio, 1996), the capture of belowground resources by plants is more dependent upon root length or root surface area than total root biomass (Nye and Tinker, 
1977; Sattelmacher et al., 1990). Differences in root morphology may affect the competitive outcome between crops and weeds.

Corn production is vital to agriculture in the United States, especially with increasing demand for global food (Tilman et al., 2002) and ethanol production. Velvetleaf is one of the most important annual weeds affecting corn and soybean production in the USA (Bridges, 1992). Because velvetleaf is a $\mathrm{C}_{3}$ species, it must invest a large amount of $\mathrm{N}$ in the carbon dioxide fixation catalyst ribulose bisphosphate carboxylase (Rubisco). Therefore, it has lower photosynthetic $\mathrm{N}$ use efficiency (PNUE) than corn, a $\mathrm{C}_{4}$ species (Brown, 1978, 1985; Sage and Pearcy, 1987). When N is limiting, velvetleaf will have to increase its $\mathrm{N}$ uptake more than corn in order to maintain the same rate of photosynthesis in new leaves. It may do this by 1) increasing the amount of biomass it allocates to roots, 2) altering its root morphological characteristics, 3) increasing the $\mathrm{N}$ uptake efficiency of roots, or 4) some combination of these factors.

Bonifas et al. (2005) showed that both corn and velvetleaf increase the fraction of new biomass partitioned to roots when $\mathrm{N}$ supply is limiting, but that velvetleaf partitions proportionally less new biomass to roots than to shoots than corn at all sizes and levels of $\mathrm{N}$ supply. However, Bonifas and Lindquist (2006) showed that velvetleaf had greater $\mathrm{N}$ uptake efficiency ( $\mathrm{N}$ uptake per unit root biomass) than corn. The smaller root biomass but larger uptake efficiency of velvetleaf may occur if velvetleaf had more root surface area per unit biomass than corn.

As $\mathrm{N}$ supply decreases, velvetleaf may change its root morphology more than corn by investing a greater fraction of its total biomass into fine root production. Fine roots are important because they are the main pathways for nutrient absorption into the plant (Eissenstat, 1992) and because they come into contact with the largest volume of soil per unit root volume (McCully, 1999). Fine roots are also an important component of Nye and Tinker's (1977) nutrient uptake equation:

$$
\mathrm{U}=2 \pi \mathrm{r}_{\mathrm{o}} \mathrm{L}_{\mathrm{v}} \mathrm{aCI} \text { o }
$$

where $\mathrm{U}$ is $\mathrm{N}$ uptake $\left(\mu \mathrm{mol} \mathrm{cm}{ }^{-3} \mathrm{~d}^{-1}\right) \mathrm{r}_{\mathrm{o}}$ is root radius $(\mathrm{cm}), \mathrm{L}_{\mathrm{v}}$ is root length density ( $\mathrm{cm}$ root $/ \mathrm{cm}^{3}$ soil), $\alpha$ is root absorbing power $\left(\mathrm{cm} \mathrm{s}^{-1}\right)$, and $\mathrm{Cl}_{\mathrm{o}}$ is nutrient concentration at the root surface $\left(\mu \mathrm{mol} \mathrm{cm}^{-3}\right)$. All else being equal, root length density will increase exponentially with decreasing root radius. An increase in root length density will result in a concomitant increase in root surface area, which may result in a significant increase in nutrient uptake (Barber and Silberbush, 1984).

Roots with a small radius also have a higher specific root length, the ratio of root length to root biomass (Eissenstat, 1992). Plants with a high specific root length are more competitive for belowground nutrients than plants with a low specific root length (Eissenstat and Caldwell, 1989). Species with a high specific root length also are able to produce root length 
more quickly, contributing to their competitive advantage over species with a low specific root length (Caldwell and Richards, 1986).

Changes in root morphological characteristics will affect corn and velvetleaf $\mathrm{N}$ uptake. The amount of $\mathrm{N}$ taken up per unit fine root length can be used as an index of $\mathrm{N}$ uptake efficiency. Greater $\mathrm{N}$ uptake per unit fine root length is an indicator of greater $\mathrm{N}$ uptake efficiency. Plants with high $\mathrm{N}$ uptake per unit fine root length do not need to invest as much biomass in fine root production as plants with low $\mathrm{N}$ uptake per unit fine root length.

Because velvetleaf is capable of causing up to $80 \%$ yield loss in corn (Lindquist et al., 1996), it is important to understand how root morphological features may contribute to the abilities of corn and velvetleaf to take up $\mathrm{N}$ when it is limiting. Changes in root morphology, such as an increase in the amount of fine roots produced, may allow velvetleaf to compete with corn for soil $\mathrm{N}$ and remain competitive for light. The objective of this research was to assess changes in corn and velvetleaf root morphological characteristics over time and in response to $\mathrm{N}$ supply.

\section{Materials and Methods}

Field experiments were conducted in 2001 and 2002 at the University of Nebraska in Lincoln, NE, USA. Plants were grown in large pots $(28 \mathrm{~cm}$ diameter by $60 \mathrm{~cm}$ deep) filled with a 50:50 sand:soil mixture and embedded in the ground to emulate the rhizosphere temperature environment of field grown plants. Each pot had $71.8 \mathrm{~cm}$ diameter holes in their bottom to allow for drainage. Pots were buried flush with the soil surface on $1 \mathrm{~m}$ centers. Rows of corn were planted between the rows of pots and around the edge of the site to more closely simulate field conditions and provide an added wind buffer for the treated plants in 2002. Total density, including potted plants, was one plant $\mathrm{m}^{-2}$ in 2001 and 5 plants $\mathrm{m}^{-2}$ in 2002.

The experiment was arranged in three replicate blocks across a $3 \%$ slope in a randomized complete block design. Blocks contained 10 replicate sample pots per treatment to accommodate for weekly destructive sampling. Each pot contained one corn or velvetleaf plant and received one of three nitrogen $(\mathrm{N})$ treatments. The $\mathrm{N}$ treatments administered were 0,1 , or $3 \mathrm{~g}$ $\mathrm{N}$ per pot in 2001, and 0,2 , or $6 \mathrm{~g} \mathrm{~N}$ per pot in 2002. The $\mathrm{N}$ treatments were increased in 2002 because corn plants reached a maximum biomass of over $300 \mathrm{~g}$ plant in 2001. Assuming a whole plant $\mathrm{N}$ concentration of $2 \%$, a $300 \mathrm{~g}$ plant requires $6 \mathrm{~g} \mathrm{~N}$. Therefore, the increase was made to ensure adequate $\mathrm{N}$ supply for corn to reach its potential biomass in 2002. The $\mathrm{N}$ treatments were applied at planting in the form of ammonium nitrate dissolved in $500 \mathrm{~mL}$ distilled water. Macro and micronutrients other than $\mathrm{N}$ were non-limiting and provided by means of a weekly addition of $250 \mathrm{~mL}$ of a dilute nutrient solution containing $(\mathrm{g})$ : potassium $(0.15$ potassium chloride; $\mathrm{KCl}$ ), calcium (0.31 calcium chloride; $\mathrm{CaCl}_{2}$ ), magnesium (0.09 mag- 
nesium sulfate; $\mathrm{MgSO}_{4}$ ), phosphorus (0.04 potassium phosphate; $\left.\mathrm{KH}_{2} \mathrm{PO}_{4}\right)$, boron $\left(5.1 \times 10^{-4}\right.$ boric acid; $\left.\mathrm{H}_{3} \mathrm{BO}_{3}\right)$, manganese $\left(5.9 \times 10^{-4}\right.$ manganese chloride; $\left.\mathrm{MnCl}_{2}\right)$ zinc $\left(2.2 \times 10^{-4}\right.$ zinc sulfate; $\left.\mathrm{ZnSO}_{4}\right)$ copper $\left(5.0 \times 10^{-5}\right.$ copper sulfate; $\left.\mathrm{CuSO}_{4}\right)$, molybdenum $\left(6.5 \times 10^{-5}\right.$ sodium molybdate; $\left.\mathrm{Na}_{2} \mathrm{MoO}_{4}\right)$, and iron $\left(2.2 \times 10^{-3}\right.$ iron chloride; $\left.\mathrm{FeCl}_{3}\right)$. Soil water supply was measured weekly and added as needed with a drip irrigation system to maintain adequate soil moisture throughout the experiment.

Plants were destructively sampled weekly in all treatments for ten weeks during the growing season. Corn reached R1 to R2 (anthesis to blister) and velvetleaf began to flower at 10 weeks. Sampling began one week after emergence in 2001 and two weeks after emergence in 2002. Plant height and growth stage were recorded and plants were cut at the soil surface at each sampling date. Aboveground plant parts were separated into stems, leaves, dead leaves, and reproductive tissues. Sampled pots were pulled from the ground and roots carefully separated from the soil mixture using a gentle stream of water. After 10 weeks of plant growth there was no obvious constriction of root growth and roots rarely grew outside the pot bottom.

Root systems were separated into coarse roots, fine roots, and brace roots, with coarse roots measuring $2 \mathrm{~mm}$ or greater in diameter, fine roots measuring less than $2 \mathrm{~mm}$ in diameter, and brace roots being those roots that originated on the corn stalk above the soil surface. Representative subsamples from each coarse root, fine root, and brace root sample were taken. Coarse root and brace root subsamples weighed approximately $1 \mathrm{~g}$ (dry weight) and fine root subsamples weighed approximately $0.2 \mathrm{~g}$ (dry weight). Images of unstained subsamples were scanned at $400 \mathrm{dpi}$ resolution using the WinRhizo Pro root scanning software system (version 5.0; Regent Instruments Inc., Quebec, Canada) at the automatic threshold selection setting (Bouma et al., 2000).

Root samples and subsamples were dried at $60^{\circ} \mathrm{C}$ to a constant weight. The fraction of fine roots produced by each plant was calculated as a function of total root weight. The root scanning software was used to calculate the root radius, root length and root volume from the image of each scanned subsample. Based on the dry weights of the subsamples and the dry weights of the entire root samples, root length and root volume were then calculated for the entire root system of each plant, and specific root length ( $\mathrm{cm}$ root $\mathrm{g}^{-1} \mathrm{root}$ ) and root length density ( $\mathrm{cm}$ root $\mathrm{cm}^{-3}$ soil) of each plant were calculated.

Soil samples were taken at each sampling date prior to extraction of the root systems by scooping approximately $200 \mathrm{~g}$ of soil from the top of each pot. Soil samples were weighed, dried, and re-weighed to determine soil water content and ensure that water was being adequately and consistently supplied. Soil temperature was monitored both inside and outside pots to determine any temperature differences at five and three randomly selected locations in 2001 and 2002, respectively. Pairs (one inside and one outside the pot) of temperature loggers (Optic StowAway, Onset Computer Corpo- 
ration, Bourne, MA, USA) were placed $5 \mathrm{~cm}$ below the soil surface to log hourly temperatures throughout the experiment.

Statistical analysis was conducted using the SAS System for Windows, version 8 (SAS Institute Inc., Cary, NC, USA). A quadratic model in the Proc Mixed procedure was used to detect differences in the fraction of fine roots, mean fine root radius, specific root length, root length density, and $\mathrm{N}$ uptake per unit fine root length in response to plant species, plant size, the amount of $\mathrm{N}$ applied, and their interactions. Plant species varied significantly (either main effect or interaction term) for all root characteristics, so all reported analyses were conducted separately by species. The fraction of fine roots, mean fine root radius, specific root length, root length density, and $\mathrm{N}$ uptake per unit fine root length were plotted as a function of plant size and second order polynomial curves were fitted for each species at each $\mathrm{N}$ level.

\section{Results and Discussion}

Measurements of gravimetric soil water content indicated adequate water availability throughout the experiment, and soil temperature did not vary sufficiently from soils outside the pots to affect root growth (Bonifas et al., 2005).

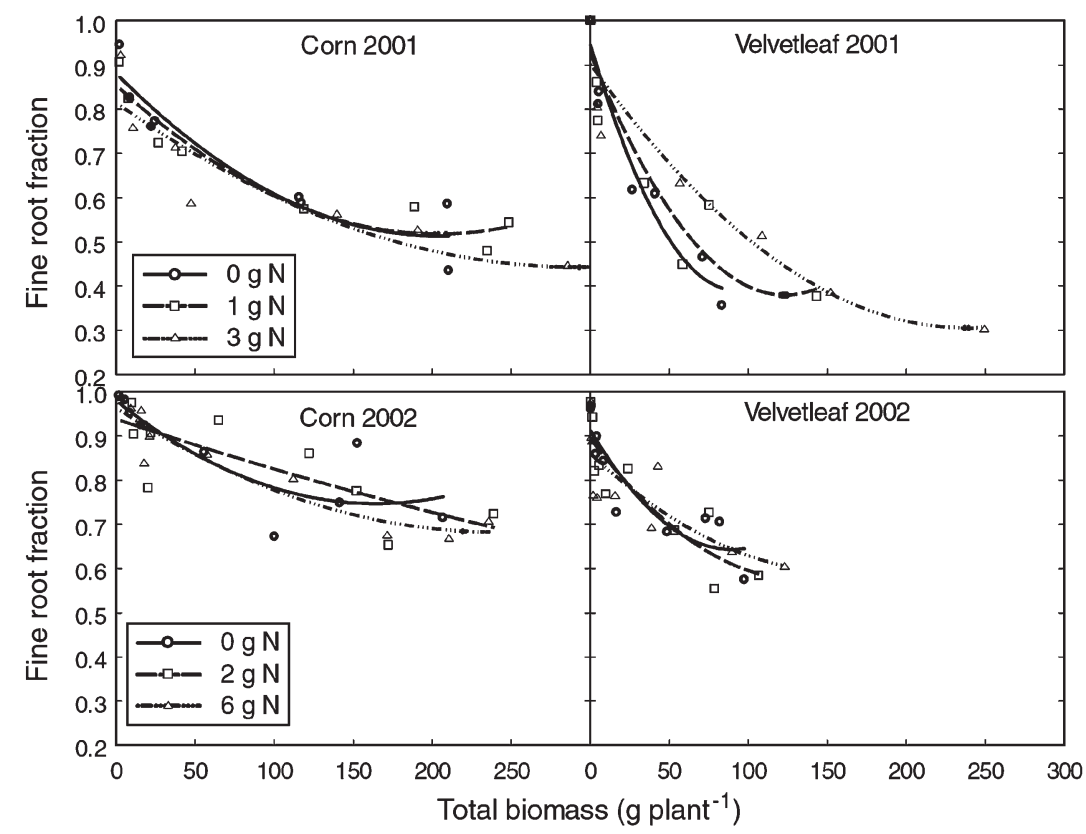

Figure 1. Corn and velvetleaf fine root fraction ( $\mathrm{g}$ fine root $\mathrm{g}$ total $\operatorname{root}^{-1}$ ) plotted as a function of total plant biomass in 2001 and 2002. Curves represent best fit second order polynomial regressions. 
The fraction of corn and velvetleaf fine roots decreased as a result of normal plant growth and development (Table 1 \& Figure 1). Velvetleaf had a greater fraction of fine roots than corn when the plants were small, but as plants became larger the fraction of fine roots declined to a level that was lower than corn in 2001. Corn fine root fraction was greater than that of velvetleaf at all plant sizes in 2002 (Figure 1). This occurred because the first sampling date took place when the plants were older and larger in

Table 1. Probability values for the test that root morphological characteristics did not vary with plant size, nitrogen treatment, or their interactions in 2001 and 2002

\begin{tabular}{|c|c|c|c|c|}
\hline \multirow[b]{2}{*}{ Parameter } & \multicolumn{2}{|c|}{ Corn } & \multicolumn{2}{|c|}{ Velvetleaf } \\
\hline & $\begin{array}{c}2001 \\
(p \text { value })\end{array}$ & $\begin{array}{c}2002 \\
(p \text { value })\end{array}$ & $\begin{array}{c}2001 \\
\text { ( } p \text { value) }\end{array}$ & $\begin{array}{c}2002 \\
(p \text { value })\end{array}$ \\
\hline \multicolumn{5}{|l|}{ Fine Root Fraction } \\
\hline Size & $<0.001$ & $<0.001$ & $<0.001$ & $<0.001$ \\
\hline Nitrogen & 0.74 & 0.88 & 0.005 & 0.40 \\
\hline Size*Nitrogen & 0.04 & 0.31 & $<0.001$ & 0.13 \\
\hline Size ${ }^{\star}$ Size & $<0.001$ & 0.001 & $<0.001$ & 0.003 \\
\hline Size ${ }^{\star}$ Size*Nitrogen & 0.09 & 0.17 & $<0.001$ & 0.18 \\
\hline \multicolumn{5}{|l|}{ Mean Fine Root Radius } \\
\hline Size & $<0.001$ & $<0.001$ & 0.002 & $<0.001$ \\
\hline Nitrogen & 0.006 & 0.05 & 0.03 & 0.47 \\
\hline Size*Nitrogen & 0.44 & 0.99 & 0.33 & 0.22 \\
\hline Size*Size & 0.37 & 0.95 & 0.05 & 0.15 \\
\hline Size*Size*Nitrogen & 0.08 & 0.73 & 0.06 & 0.89 \\
\hline \multicolumn{5}{|l|}{ Root Length Density } \\
\hline Size & $<0.001$ & $<0.001$ & $<0.001$ & $<0.001$ \\
\hline Nitrogen & 0.02 & 0.003 & 0.99 & 0.29 \\
\hline Size*Nitrogen & 0.03 & $<0.001$ & 0.59 & 0.15 \\
\hline Size*Size & 0.002 & 0.53 & $<0.001$ & 0.89 \\
\hline Size*Size*Nitrogen & 0.09 & $<0.001$ & 0.67 & 0.61 \\
\hline \multicolumn{5}{|l|}{ Specific Root Length } \\
\hline Size & $<0.001$ & 0.005 & 0.51 & $<0.001$ \\
\hline Nitrogen & 0.004 & 0.01 & 0.002 & 0.37 \\
\hline Size*Nitrogen & 0.10 & 0.63 & $<0.001$ & 0.05 \\
\hline Size*Size & 0.30 & 0.02 & 0.90 & 0.51 \\
\hline Size*Size*Nitrogen & 0.07 & 0.73 & 0.23 & 0.96 \\
\hline \multicolumn{5}{|c|}{$\mathrm{N}$ uptake per unit fine root } \\
\hline Size & 0.01 & $<0.001$ & $<0.001$ & 0.008 \\
\hline Nitrogen & $<0.001$ & $<0.001$ & 0.21 & 0.29 \\
\hline Size*Nitrogen & 0.30 & 0.36 & 0.06 & 0.99 \\
\hline Size ${ }^{\star S i z e}$ & 0.004 & 0.03 & 0.12 & 0.33 \\
\hline Size*Size*Nitrogen & 0.72 & 0.44 & 0.23 & 0.94 \\
\hline
\end{tabular}




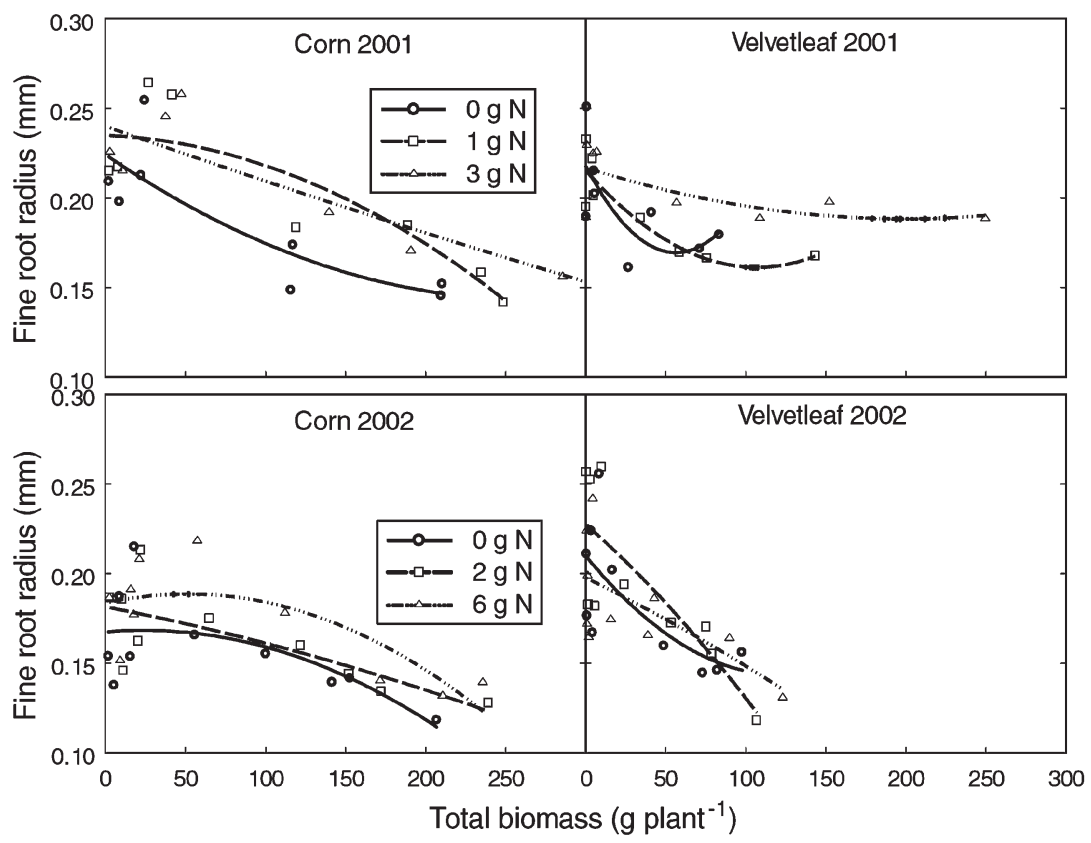

Figure 2. Corn and velvetleaf mean fine root radius $(\mathrm{mm})$ plotted as a function of total plant biomass $\left(\mathrm{g} \mathrm{plant}^{-1}\right.$ ) in 2001 and 2002. Curves represent best fit second order polynomial regressions.

2002 than in 2001. The large taproot of velvetleaf was included as a coarse root in root biomass calculations; as the plants grew this taproot also grew much larger, which contributed to the decrease in the weight fraction of fine roots for velvetleaf.

Corn fine root fraction was greater at low nitrogen $(\mathrm{N})$ supply during early and late growth in 2001, but did not vary with N supply in 2002 (Table 1 \& Figure 1). Fraction of velvetleaf fine roots increased with increasing $\mathrm{N}$ supply in 2001, but did not vary with $\mathrm{N}$ treatment in 2002. An increase in the amount of fine roots produced would lead to an increase in total root surface area, allowing the roots to come into contact with a larger volume of soil and increase $\mathrm{N}$ uptake.

Mean radius $(\mathrm{mm})$ of corn and velvetleaf fine roots decreased with increasing plant size in both years (Table 1 \& Figure 2). Velvetleaf fine root radius was similar to that of corn during early growth in 2001, but declined to a level below that of corn at similar biomass. In 2002, velvetleaf fine root radius was greater than that of corn during early growth, but quickly declined to a radius that was smaller than that of corn at similar biomass. Corn fine root radius decreased with decreasing $\mathrm{N}$ supply in both years, whereas velvetleaf fine root radius declined with decreasing $\mathrm{N}$ supply only in 2001. 


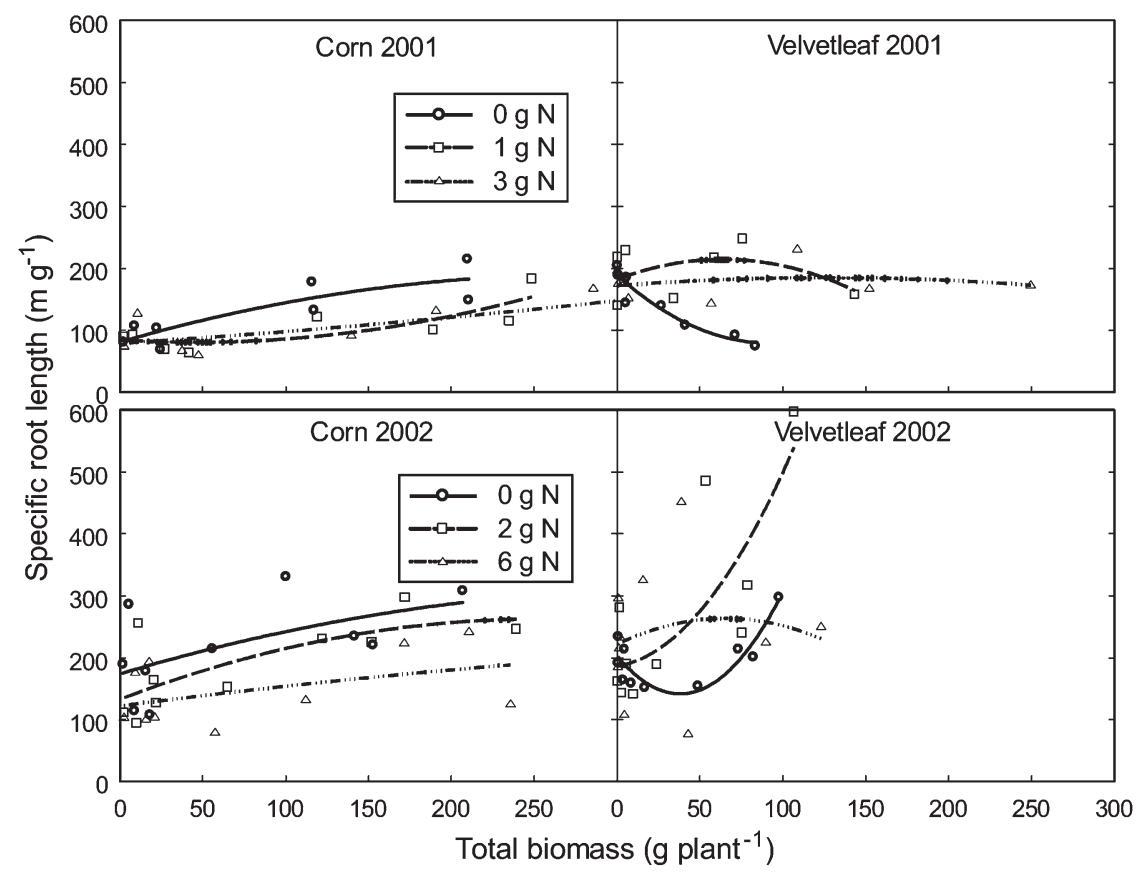

Figure 3. Corn and velvetleaf specific root length ( $\mathrm{m} \mathrm{root}^{-1}$ root) plotted as a function of total plant biomass ( $\mathrm{g}$ plant ${ }^{-1}$ ) in 2001 and 2002. Curves represent best fit second order polynomial regressions.

Corn specific root length (SRL, $\mathrm{cm}$ root $\mathrm{g}^{-1}$ root) increased with increasing plant size and $\mathrm{N}$ supply in both years (Table 1 \& Figure 3). Velvetleaf SRL was greater than that of corn at all plant sizes in all treatments but the $0 \mathrm{~N}$ treatment in 2001. Velvetleaf SRL did not vary with $\mathrm{N}$ treatments in 2002. Greater SRL would result in greater root surface area at a given root biomass.

Smaller root radius and greater SRL generally result in greater root length density $\left(\mathrm{L}_{\mathrm{v}^{\prime}} \mathrm{cm}\right.$ root $\mathrm{cm}^{-3}$ soil). Corn and velvetleaf $\mathrm{L}_{\mathrm{v}}$ increased as the plants grew larger in both years (Table $1 \&$ Figure 4). Corn growing in the $0 \mathrm{~N}$ treatment had the greatest $\mathrm{L}_{\mathrm{v}}$ at all plant sizes in both years. Velvetleaf and corn $\mathrm{L}_{\mathrm{v}}$ in the higher $\mathrm{N}$ addition treatments showed similar $\mathrm{L}_{\mathrm{v}}$ at the same biomass up to about $100 \mathrm{~g} \mathrm{plant}^{-1}$ in both years. However, large corn plants (> $\left.100 \mathrm{~g} \mathrm{plant}^{-1}\right)$ always had greater $\mathrm{L}_{\mathrm{v}}$ than velvetleaf.

Nitrogen uptake efficiency (UE) was measured using $\mathrm{N}$ uptake per unit fine root length ( $\mathrm{g} \mathrm{N} 100 \mathrm{~m}^{-1}$ fine root). Corn and velvetleaf UE decreased as plant size increased in 2001 and 2002 (Table 1 \& Figure 5). Corn UE increased with increasing $\mathrm{N}$ supply in both years. Velvetleaf UE was greater than that of corn across all plant sizes in most $\mathrm{N}$ treatments, but did not vary with $\mathrm{N}$ supply treatment in either year. 


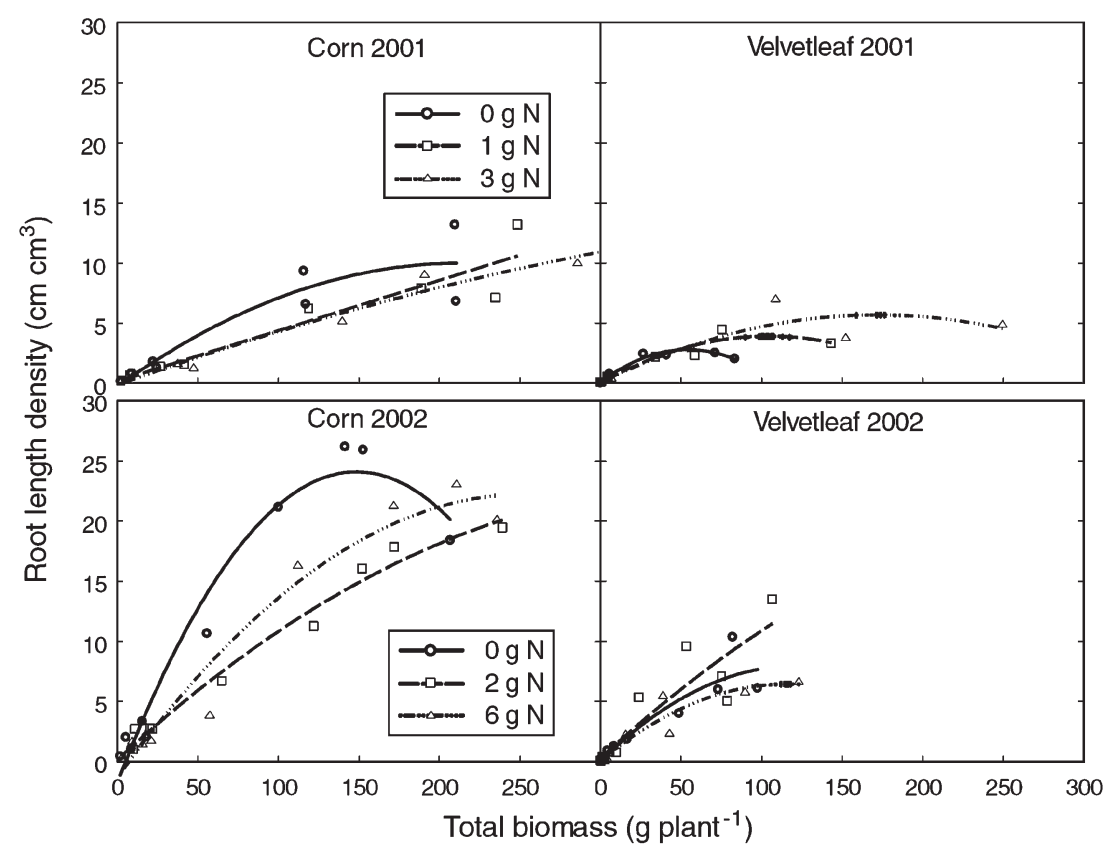

Figure 4. Corn and velvetleaf root length density ( $\mathrm{cm}$ root $\mathrm{cm}^{-3}$ soil) plotted as a function of total plant biomass $\left(\mathrm{g} \mathrm{plant}^{-1}\right.$ ) in 2001 and 2002. Curves represent best fit second order polynomial regressions.

Bonifas et al. (2005) showed that both corn and velvetleaf increase the fraction of new biomass partitioned to roots when $\mathrm{N}$ supply is limiting. This does not mean that $\mathrm{N}$ deficient corn and velvetleaf will have greater root biomass. Rather, if overall plant growth rate is reduced by $\mathrm{N}$ deficiency, the optimum result is that root biomass does not decline with $\mathrm{N}$ deficiency as much as shoot biomass. Since root biomass may still be smaller, it is reasonable that plants may modify their root morphology to further aid their capacity to take in nutrients. While velvetleaf had less root biomass overall than corn, Bonifas and Lindquist (2006) showed that velvetleaf had

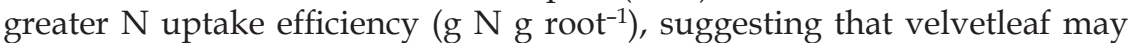
have more roots with smaller radius and/or greater specific root length, which would increase the surface area available for $\mathrm{N}$ uptake.

Velvetleaf had a greater fraction of fine roots than corn when plants were small (Figure 1). While those fine roots were similar in radius to corn roots when plants were small, their specific root length was greater. At moderate plant size $\left(\sim 100 \mathrm{~g}_{\text {plant }}{ }^{-1}\right)$, velvetleaf fine roots had smaller radius than corn, but similar SRL. The end result was that even though velvetleaf had considerably less root biomass than corn, their root length density was similar during much of the vegetative period when $\mathrm{N}$ was not deficient. Thus, velvetleaf was able to increase the total length of its root system with 


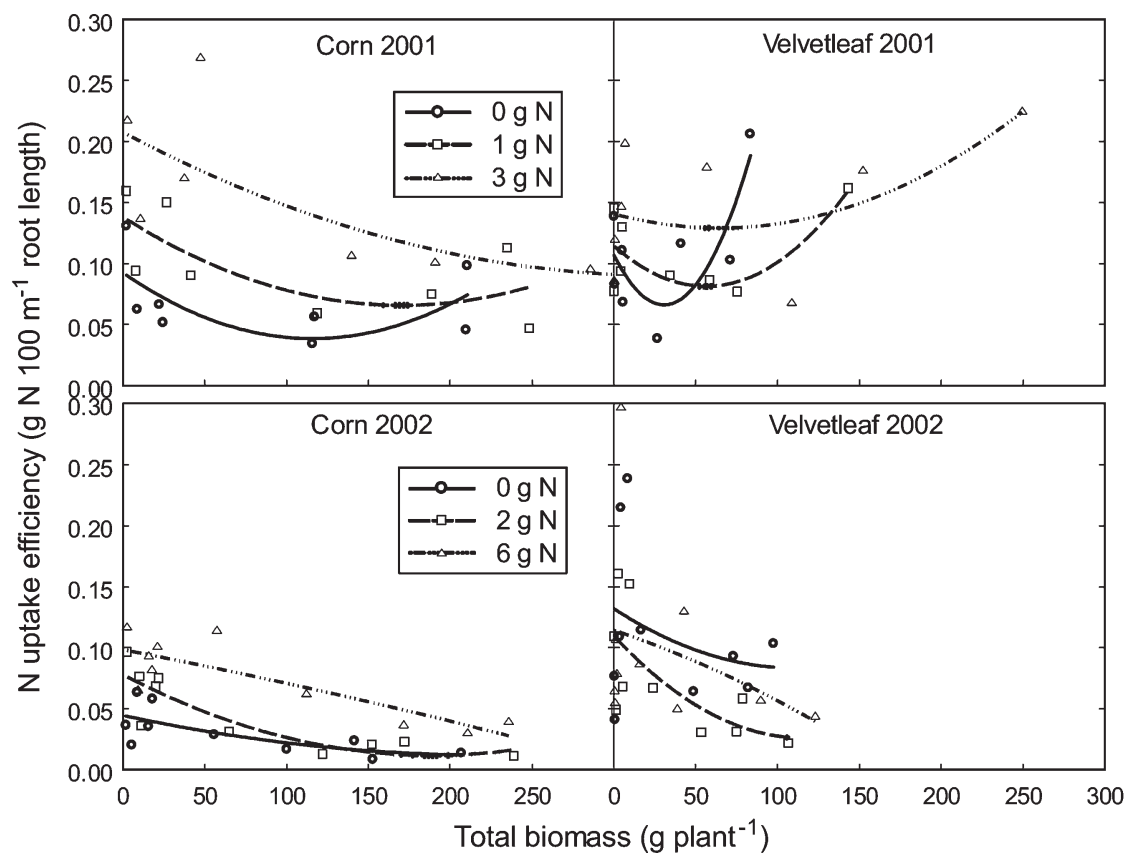

Figure 5. Corn and velvetleaf nitrogen uptake per unit fine root length (g N $100 \mathrm{~m}^{-}$ ${ }^{1}$ root length) plotted as a function of total plant biomass (g plant ${ }^{-1}$ ) in 2001 and 2002. Curves represent best fit second order polynomial regressions.

a smaller biomass investment than corn (Eissenstat, 1992), which may contribute to greater competitiveness for belowground nutrients (Eissenstat and Caldwell, 1989). By investing less biomass to produce root length, velvetleaf also will be able to maintain biomass partitioning to aboveground plant parts and remain competitive for light.

Corn root morphological characteristics appear to respond more to $\mathrm{N}$ supply than velvetleaf. Corn root radius declined, specific root length increased and root length density increased when $\mathrm{N}$ was deficient. These characteristics should benefit the ability of corn to compete for N. While velvetleaf fine root radius, specific root length and root length density did not consistently vary with $\mathrm{N}$ supply, $\mathrm{N}$ deficiency reduced velvetleaf fine root fraction and specific root length in 2001. These results suggest that, in lieu of further reducing root radius and specific root length relative to that of corn, velvetleaf may invest more root biomass in the production of a deeper tap root to reach nutrients deeper in the profile.

Corn and velvetleaf root morphological characteristic differences give insight as to how each species competes for and takes up N. Both corn and velvetleaf alter certain root morphological characteristics in response to $\mathrm{N}$ 
supply, but corn responds much more than velvetleaf. Since velvetleaf has greater $\mathrm{N}$ uptake per unit root length than corn, it may make sense that it invest more energy in placing some of its roots below the corn root system. Knowing how the root morphology of corn and velvetleaf differ in response to $\mathrm{N}$ supply will lead to a better understanding of how the two species compete with one another for both belowground resources such as $\mathrm{N}$ and aboveground resources such as light.

\section{Acknowledgments}

This research is a contribution of the University of Nebraska Agricultural Research Division, Lincoln, NE. This research was supported in part by funds provided by the Hatch Act and by the State of Nebraska.

\section{References}

Barber, S. A. and Silberbush, M. (1984) Plant root morphology and nutrient uptake, in Barber, S. A. and Bouldin, D. R. (eds.), Roots, Nutrient and Water Influx, and Plant Growth (Madison, WI: American Society of Agronomy), pp. 65-87.

Bonifas, K. D. and Lindquist, J. L. (2006) Predicting biomass partitioning to root versus shoot in corn and velvetleaf (Abutilon theophrasti). Weed Science 54, pp. 133-137.

Bonifas, K. D., Walters, D. T., Cassman, K. G., and Lindquist, J. L. (2005) Nitrogen supply affects root:shoot ratio in corn and velvetleaf (Abutilon theophrasti). Weed Science 53, pp. 670-675.

Bouma, T. J., Nielsen, K. L., and Koutstaal, B. (2000) Sample preparation and scanning protocol for computerized analysis of root length and diameter. Plant and Soil 218, pp. 185-196.

Bridges, D. C. (1992) Crop losses due to weeds in the United States - 1992 Weed Science Society of America, Champaign, IL

Brown, R. H. (1978) A difference in N use efficiency in $C_{3}$ and $C_{4}$ plants and its implications in adaptation and evolution. Crop Science 18, pp. 93-98.

Brown, R. H. (1985) Growth of $\mathrm{C}_{3}$ and $\mathrm{C}_{4}$ grasses under low $\mathrm{N}$ levels. Crop Science 25, pp. 954-957.

Caldwell, M. M. and Richards, J. H. (1986) Competing root systems: Morphology and models of absorption, in Givnish, T. J. (ed.) On the Economy of Plant Form and Function (New York: Cambridge University Press), pp. 251-273.

Eissentstat, D. M. (1992) Costs and benefits of constructing roots of small diameter. Journal of Plant Nutrition 15, pp. 763-782.

Eissenstat, D. M. and Caldwell, M. M. (1989) Invasive root growth into disturbed soil of two tussock grasses that differ in competitive effectiveness. Functional Ecology 3, pp. 345-353.

Hilbert, D. W. (1990) Optimization of plant root:shoot ratios and internal nitrogen concentration. Annals of Botany 66, pp. 91-99. 
Lindquist, J. L., Mortensen, D. A., Clay, A., Schmenk, R., Kells, J. J., Howatt, K., and Westra, P. (1996) Stability of corn (Zea mays)-velvetleaf (Abutilon theophrasti) interference relationships. Weed Science 44, pp. 309-313.

McCully, M. E. (1999) Roots in soil: Unearthing the complexities of roots and their rhizospheres. Annual Review of Plant Physiology and Plant Molecular Biology 50, pp. 695-718.

Mooney, H. A., Bloom, A. J., and Chapin III, F. S. (1985) Resource limitation in plants-an economic analogy. Annual Review of Ecology Systematics 16, pp. 363-392.

Nye, P. H. and Tinker, P. B. (1977) Solute Movement in the Soil-Root System Blackwell Scientific Publications, Oxford

Reynolds, H. L. and D'Antonio, C. (1996) The ecological significance of plasticity in root weight ratio in response to nitrogen: Opinion. Plant and Soil 185, pp. 75-97.

Robinson, D. (1986) Compensatory changes in the partitioning of dry matter in relation to nitrogen uptake and optimal variations of growth. Annals of Botany 58, pp. 841-848.

Sage, R. F. and Pearcy, R. W. (1987) The nitrogen use efficiency of $C_{3}$ and $C_{4}$ plants. Plant Physiology 84, pp. 954-958.

Sattelmacher, B., Klotz, F., and Marschner, H. (1990) Influence of the nitrogen level on root growth and morphology of two potato varieties differing in nitrogen acquisition. Plant and Soil 123, pp. 131-137.

Tilman, D., Cassman, K. G., Matson, P. A., Naylor, R., and Polasky, S. (2002) Agricultural sustainability and intensive production practices. Nature 418, pp. 671-677. 